\title{
Hubungan Komunikasi Dokter-Pasien Terhadap Kepuasan Pasien Berobat Di Poliklinik RSUP DR. M. Djamil Padang
}

\author{
Tiara Wahyuni ${ }^{1}$, Amel Yanis $^{2}$, Erly $^{3}$
}

\begin{abstract}
Abstrak
Komunikasi dokter - pasien adalah suatu hal yang sangat penting dalam proses terapeutik di rumah sakit. Kualitas komunikasi yang terjadi diantara kedua belah pihak akan menghasilkan kepuasan di dalam diri pasien karena pasien akan merasa puas dan kembali lagi ke dokter yang sama jika komunikasi mereka baik dan efektif. Penelitian ini bertujuan untuk mengetahui hubungan komunikasi dokter - pasien dengan kepuasan pasien berobat di poliklinik RSUP dr. M. Djamil Padang. Desain penelitian adalah Cross Sectional dengan teknik pengambilan subjek yaitu proportionate stratified random sampling dengan jumlah 107 orang. Data diolah dan dianalisis menggunakan program komputer SPSS 17 dengan uji statistik chi-square. Hasil analisis univariat menunjukkan komunikasi dokter - pasien cukup baik yaitu $46,7 \%$ dan tingkat kepuasan pasien yaitu $86,9 \%$. Hasil analisis bivariat secara umum menunjukkan ada hubungan bermakna antara komunikasi dokter - pasien terhadap kepuasan pasien. Kesimpulan dari hasil penelitian ini ialah terdapat hubungan yang bermakna antara komunikasi dokter - pasien terhadap kepuasan pasien berobat di poliklinik RSUP dr. M. Djamil Padang.
\end{abstract}

Kata kunci: komunikasi, kepuasan

\begin{abstract}
Communications doctor - patient is a very important thing in the therapeutic process in a hospital. Quality of the communication between two parties will result in the patient satisfaction because patients will feel satisfied and come back to the same doctor if they are good and effective communication. This study aimed to determine the relationship of doctor communication - patient to patient satisfaction for treatment in the policlinic Dr M. Djamil Padang. The design of study was cross-sectional sampling technique that is proportionate stratified random sampling with a total sample of 107 people. Data were processed and analyzed using the computer program SPSS 17 with chi-square test. The results of univariate analysis showed doctor communication quite enough that patients and $46.7 \%$ patient satisfaction rate is $86.9 \%$. The results of the bivariate analyzes in general showed significant relationship between doctor communication - patient to patient satisfaction in the RSUP dr. M Djamil Padang.
\end{abstract}

Keywords: communication, satisfication

Affiliasi penulis : ${ }^{1}$ Mahasiswa FK Unand, ${ }^{2}$ Bagian IImu Kedokteran Jiwa FK Unand, ${ }^{3}$ Bagian Mikrobiologi FK Unand

Korespondensi : Fakultas Kedokteran Universitas Andalas J.

Perintis Kemerdekaan No.94, Padang.

Email:'wahyuni.tiara@rocketmail.com

Telp: 0751-79502077

\section{PENDAHULUAN}

Berdasarkan Peraturan Menteri Kesehatan RI Nomor 159b/Menkes/PER/II/1998 tentang Rumah Sakit : rumah sakit didefinisikan sebagai sarana upaya kesehatan yang menyelenggarakan kegiatan pelayanan kesehatan serta dapat dimanfaatkan untuk pendidikan tenaga kesehatan dan penelitian. Survei global terbaru yang dilakukan di tujuh Negara yaitu Inggris, Jerman,Itali, Korea, Meksiko, Spanyol, dan Finlandia mengungkapkan bahwa komunikasi efektif dokter dengan pasien adalah kunci pada perawatan dan diagnosis yang akurat dan lebih awal pada pasien nyeri saraf. Menurut kesimpulan yang dirangkum oleh American Society of Internal Medicine, komunikasi yang baik ternyata berhasil menurunkan angka keluhan dan tuntutan hukum terhadap dokter. Sebagian pasien mengeluhkan layanan dokter bukan karena kemampuan dokter tersebut kurang namun karena mereka merasa kurang diperhatikan. Dokter hendaknya bersedia mendengarkan dengan baik dan tidak menunjukkan sikap tergesa-gesa. ${ }^{1}$

Fungsi rumah sakit sebagai sarana pelayanan kesehatan untuk pasien akan terlihat pada suatu penelitian dengan mengetahui mengapa pasien tidak kembali. Beberapa alasan yang menyebabkan pasien tidak kembali ke rumah sakit adalah $1 \%$ karena meninggal dunia, 3\% karena pindah tempat tinggal, $5 \%$ karena memuaskan dengan perusahaan lain, 9\% karena bujukan pesaing, $14 \%$ karena tidak puas dengan produk dan $68 \%$ karena mutu pelayanan yang buruk. $^{2}$ Kepuasan yang dimaksud adalah suatu keadaan dimana keinginan, harapan dan kebutuhan pasien terhadap pelayanan jasa terpenuhi. Penilaian kepuasan mencakup kemampuan petugas memberikan pelayanan kepada pasien dengan cepat, tepat, dapat dipercaya, dan mampu membina hubungan baik dengan pasien. Pasien sering tidak puas dengan kualitas dan jumlah informasi yang diterima dari tenaga kesehatan, hal ini terlihat dari penelitian bahwa $35 \%$ - $40 \%$ pasien tidak puas berkomunikasi dengan dokter. ${ }^{3}$

Mutu pelayanan adalah suatu pelayanan yang diberikan kepada pasien oleh tenaga kesehatan secara profesional dengan empati, perhatian serta tanggap akan kebutuhan pasien untuk meningkatkan derajat kesehatan pasien sesuai dengan ilmu pengetahuan, keterampilan, dan standar yang berlaku. Dari hasil penelitian di RSI Sunan Kudus terhadap seratus pasien rawat jalan dan juga surat yang masuk di kotak saran sebanyak 25 buah didapatkan keluhan pasien yang menyangkut pelayanan dokter di poliklinik umum rawat jalan sebanyak $65 \%$, pelayanan bagian pendaftaran $5 \%$, pelayanan administrasi $10 \%$, pelayanan perawat dan karyawan rumah sakit $15 \%$, dan fasilitas $5 \%$. Dari data di atas keluhan pasien yang menyangkut pelayanan dokter di poliklinik umum rawat jalan menempati urutan tertinggi di banding pelayanan 
perawat, sarana, administrasi dan karyawan rumah sakit. $^{2}$

Sedangkan surat-surat yang masuk ke kotak saran RS dr. M. Djamil Padang mengalami peningkatan dari tahun 2003 ke tahun 2004. Pada tahun 2003, surat keluhan yang masuk sebanyak 13 surat dari 230.817 pasien dan tahun 2004 surat keluhan yang masuk sebanyak 33 surat dari 216.120 pasien. Surat tersebut pada umumnya mengeluhkan tentang pelayanan dokter, perawat, kesehatan lingkungan, gizi, dan informasi. ${ }^{4}$

Menurut Theodorsin (1969), komunikasi merupakan suatu proses pemindahan informasi dari satu atau sekelompok orang kepada satu atau sekelompok orang lain dengan menggunakan simbolsimbol tertentu sehingga memberikan suatu pengaruh. Komunikasi menjadi salah satu faktor penentu mutu pelayanan di rumah sakit dan kepuasan pasien merupakan salah satu indikator pelayanan yang bermutu. Berdasarkan piramida kebutuhan Abraham Maslow, untuk memenuhi berbagai kebutuhan manusia maka mereka selalu mengarahkan diri dengan tingkah laku komunikasi. ${ }^{5}$

Berdasarkan survei pendahuluan data pengunjung terbanyak di instalasi rawat jalan RSUP Dr. M. Djamil Padang pada bulan Desember 2012 adalah poli Khusus sebanyak 23.012 pasien, poli Bedah sebanyak 16.786 pasien, poli Penyakit Dalam 14.936 pasien, poli Telinga Hidung Tenggorok (THT) sebanyak 11.644 pasien dan poli Mata sebanyak 10.806 pasien. Berdasarkan data kunjungan, maka pasien lama yang menggunakan Askes terbanyak terdapat di 9 bagian sedangkan pasien non Askes terbanyak sebanyak 13 bagian. Pasien baru pengguna Askes terbanyak terdapat di 3 bagian sedangkan non Askes sebanyak 19 bagian. ${ }^{6}$ Di ruang rawat inap Bedah RSUP Dr. M. Djamil, daya tanggap dokter tidak baik sebanyak $58,8 \%$ dan $56,1 \%$ responden menyatakan empati dokter tidak baik. ${ }^{4}$ Pasca gempa bumi pada bulan September 2009, Poliklinik Umum RSUP dr. M.Djamil Padang pindah ke gedung baru yang di bangun setelah gempa. Kondisi gedung poliklinik umum yang berlantaikan semen dan cukup sempit untuk pasien yang berobat dan menunggu, tenaga kesehatan, hingga ruang pemeriksaan menyebabkan suasana yang kurang kondusif. Sebagai rumah sakit rujukan di Sumatera Barat, supaya berkualitas baik, RSUP dr. M. Djamil seharusnya memberikan pelayanan yang memuaskan kepada pasien baik dalam bentuk fasilitas maupun komunikasi antara dokter dan pasien. Jika hal ini tidak dimiliki, maka akan membuat pasien merasa tidak nyaman karena yang mereka harapkan adalah sakit ataupun keluhan mereka dapat berkurang dan hilang. Bahkan dengan komunikasi yang baik, tenaga medis maupun paramedis terhadap pasien dapat mengurangi sedikit rasa sakit yang diderita oleh pasien sehingga keahlian komunikasi di dalam konsultasi adalah suatu faktor penting untuk kepuasan pasien. $^{7}$

Pasien yang puas merupakan aset yang sangat berharga karena apabila pasien puas, maka mereka akan memakai terus-menerus jasa pilihannya, tetapi jika pasien merasa tidak puas mereka akan memberitahukan dua kali lebih hebat kepada orang lain tentang pengalaman buruknya. Untuk menciptakan kepuasan pasien suatu perusahaan atau rumah sakit harus menciptakan dan mengelola suatu sistem untuk memperoleh pasien yang lebih banyak dan kemampuan untuk mempertahankan pasiennya. Berdasarkan uraian diatas maka dilakukanlah penelitian tentang "hubungan komunikasi dokter pasien terhadap kepuasan pasien berobat di poliklinik umumRSUP Dr. M. Djamil Padang".

\section{METODE}

Penelitian dilaksanakan pada bulan Januari Maret 2013 dan wawancara dilakukan kepada pasien yang berobat di poliklinik RSUP dr. M. Djamil Padang dari tanggal 5 Maret 2013 - 18 Maret 2013. Subjek dalam penelitian ini sebanyak 107 orang dengan usia $\geq 18$ - $\leq 60$ tahun yang berobat di poliklinik RSUP dr. M. Djamil Padang dan memenuhi kriteria inklusi serta tidak memiliki kriteria eksklusi. Pemilihan sampel dilakukan dengan cara proportionate stratified random sampling dengan memperhatikan strata yang ada dalam populasi. Instrumen penelitian yang digunakan adalah kuesioner data sampel. Data yang diperoleh diolah dengan menggunakan sistem komputerisasi, dan untuk analisis hasil penelitiannya digunakan uji korelasi dengan tingkat pemaknaan $p<0,05$.

\section{HASIL DAN PEMBAHASAN}

a. Karakteristik Subjek Penelitian

1. Umur

Sebagian besar pasien berobat yang menjadi responden adalah usia 41-60 tahun. (Tabel 1)

2. Jenis Kelamin Responden terbanyak adalah perempuan.

3. Pendidikan Terakhir Responden terbanyak adalah berpendidikan SMA.

4. Pekerjaan

Pasien yang paling banyak menjadi reponden adalah tidak bekerja. (Tabel 2)

5. Suku Bangsa Seluruh pasien adalah suku Minangkabau.

6. Kunjungan Pasien Sebagian besar pasien yang berobat di rawat jalan adalah pasien lama yaitu sebesar $65,4 \%$. (Tabel 3)

7. Cara Pembayaran

Sebagian besar responden adalah pasien yang berobat dengan menggunakan Askes yaitu sebesar $45,8 \%$. (Tabel 4 )

\section{b. Analisis Univariat}

Analisis univariat berguna untuk melihat distribusi frekuensi masing-masing variabel baik variabel independen (komunikasi dokter - pasien) maupun variabel dependen (tingkat kepuasan pasien)

1. Komunikasi Dokter - Pasien

Sebagian besar responden menyatakan komunikasi dokter - pasien cukup baik.

2. Kepuasan Pasien

Sebagian besar pasien berobat di poliklinik menyatakan puas dengan dokter yang memeriksa mereka.

c. Analisis Bivariat

1. Hubungan Komunikasi Dokter - Pasien terhadap Kepuasan Pasien Berobat

Berdasarkan uji statistik pada tabel 5, tidak bisa ditentukan signifikan atau tidak signifikannya penelitian ini dikarenakan ada nilai cell yang bernilai 0 , sehingga dilakukan penggabungan cell terdekat sehingga pada tabel 6 dapat dilihat proporsi 
responden yang puas lebih banyak terjadi pada responden dengan komunikasi antara dokter dan pasien yang baik dan cukup baik bila dibandingkan dengan responden yang komunikasinya kurang baik. Hasil uji statistik dengan menggunakan chi square, diperoleh nilai $p=0,00(p<0,05)$.

\section{KESIMPULAN}

1. Sebagian besar dokter di RSUP Dr. M. Djamil Padang memiliki komunikasi yang cukup baik dengan pasien.

2. Sebagian besar pasien yang berobat di poliklinik umumRSUP Dr. M. Djamil Padang puas dengan pelayanan dokter.

3. Terdapat hubungan antara komunikasi dokter pasien dengan kepuasan pasien yang berobat di poliklinik umumRSUP Dr. M. Djamil Padang.

TABEL

Tabel 1. Distribusi responden berdasarkan kelompok umur

\begin{tabular}{lcc}
\hline Umur & Jumlah & Pasien \\
\hline 18-21 tahun & 15 & 14,0 \\
\hline $22-40$ tahun & 34 & 31,8 \\
\hline $41-60$ tahun & 58 & 54,2 \\
\hline Total & 107 & 100,0 \\
\hline
\end{tabular}

Tabel 2. Distribusi responden berdasarkan pekerjaan

\begin{tabular}{lcc}
\hline Pekerjaan & Jumlah & Persen \\
\hline PNS & 27 & 25,2 \\
\hline Karyawan swasta & 6 & 5,6 \\
\hline Wiraswasta & 13 & 12,1 \\
\hline Buruh & 3 & 2,8 \\
\hline Tidak bekerja & 41 & 38,3 \\
\hline Mahasiswa & 17 & 15,9 \\
\hline Total & 107 & 100,0 \\
\hline
\end{tabular}

Tabel 3. Distribusi responden berdasarkan kunjungan pasien

\begin{tabular}{lcc}
\hline Kunjungan & Jumlah & Persen \\
\hline Baru & 37 & 34,6 \\
\hline Lama & 70 & 65,4 \\
\hline Total & 107 & 100,0 \\
\hline
\end{tabular}

Tabel 4. Distribusi responden berdasarkan cara pembayaran
Tabel 5. Hubungan komunikasi dokter - pasien terhadap kepuasan pasien berobat

\begin{tabular}{|c|c|c|c|c|c|c|c|}
\hline \multirow{3}{*}{ Komunikasi } & \multicolumn{4}{|c|}{ Kepuasan } & \multirow{2}{*}{\multicolumn{2}{|c|}{ Total }} & \multirow{3}{*}{$\begin{array}{c}P \\
\text { value }\end{array}$} \\
\hline & \multicolumn{2}{|c|}{ Tidak Puas } & \multicolumn{2}{|c|}{ Puas } & & & \\
\hline & $\mathrm{F}$ & $\%$ & $\mathrm{~F}$ & $\%$ & $f$ & $\%$ & \\
\hline Kurang & 12 & 85,7 & 2 & 14,3 & 14 & 100 & \\
\hline Cukup & 2 & 4,0 & 48 & 96,0 & 50 & 100 & - \\
\hline Baik & 0 & 0 & 23 & 100 & 43 & 100 & \\
\hline Total & 14 & 13,1 & 93 & 86,9 & 107 & & \\
\hline
\end{tabular}

Tabel 6. Hubungan komunikasi dokter - pasien terhadap kepuasan pasien berobat

\begin{tabular}{lcccccccc}
\hline \multirow{2}{*}{ Komunikasi } & \multicolumn{4}{c}{ Kepuasan } & \multicolumn{2}{c}{ Total } & \multirow{2}{*}{$\begin{array}{c}\mathrm{P} \\
\end{array}$} & \multicolumn{3}{c}{ Tidak Puas } & \multicolumn{2}{c}{ Puas } & & & Value \\
\cline { 2 - 6 } & $\mathrm{F}$ & $\%$ & $\mathrm{~F}$ & $\%$ & $\mathrm{f}$ & $\%$ & \\
\hline Kurang & 12 & 85,7 & 2 & 14,3 & 14 & 100 & $\mathrm{P}=$ \\
Cukup \& Baik & 2 & 2,2 & 91 & 97,8 & 93 & 100 & 0,00 \\
\hline Total & 14 & 13,1 & 93 & 86,9 & 107 & & \\
\hline
\end{tabular}

\section{UCAPAN TERIMA KASIH}

Ucapan terima kasih kepada dr. Amel Yanis, Sp.KJ (K) dan Ibu dr. Erly, Sp.MK atas bimbingan, bantuan, dan motivasi dalam penelitian ini.

\section{DAFTAR PUSTAKA}

1. Djauzi, Samsuridjal, Supartondo. Komunikasi dan empati, dalam hubungan Dokter Pasien, Jakarta: Fakultas Kedokteran, Universitas Indonesia; 2004

2. Hilal, A. Persepsi pasien terhadap mutu pelayanan (tesis). Universitas Diponegoro; 2005.

3. Smet. Psikologi kesehatan. Jakarta: PT. Grasindo; 1994.

4. Mardona Y. Hubungan dimensi mutu pelayanan dokter dan perawat dengan tingkat kepuasan pasien di ruang rawat Inap bedah RS dr. M. Djamil Padang. 2005.

5. Liliweri A. Komunikasi antar pribadi. Bandung: PT Citra Aditya Bakti; 1997.

6. Data Rekam Medik Kunjungan Pasien Instalasi Rawat Jalan RSUP Dr. M. Djamil Padang bulan Desember 2012. Data diambil pada bulan Februari 2013.

7. Albery PI, Munafo M. Psikologi kesehatan. Yogyakarta: Mitra Setia; 2011.

\begin{tabular}{lcc}
\hline \multicolumn{1}{c}{ Pembayaran } & Jumlah & Persen \\
\hline Askes & 49 & 45,8 \\
\hline Jamkesmas & 38 & 35,5 \\
\hline Jamkesda & 4 & 3,7 \\
\hline Umum & 14 & 13,1 \\
\hline Lainnya & 2 & 1,9 \\
\hline Total & 107 & 100,0 \\
\hline
\end{tabular}

